\title{
Pemanfaatan Media Sosial Instagram Koalisi Pemuda Hijau Indonesia (KOPHI) Sebagai Media Publikasi Kegiatan
}

\author{
Handini Prabawati, Wasono Adi \\ D III Hubungan Masyarakat, Fakultas Ilmu Sosial, Universitas Negeri Jakarta \\ Email: handiniprabawati2@gmail.com, adwasono35@gmail.com \\ Diterima 20 November 2019 / Disetujui 24 Desember 2019
}

\begin{abstract}
Koalisi Pemuda Hijau Indonesia (KOPHI), a community engaged in the environment, often discusses issues and phenomena that occur at that time. In carrying out their activities, Media and Communication (MedCom) team utilized instagram social media as a media publication activity, descriptive study: on the instagram account @_kophi. However, the low instagram engagement is an obstacle in gaining feedback from followers. The purpose of this study is to find out how to use instagram@_kophisocial media throughtseveral stages of share, manage, optimize, and manage. This research uses the main theory of social media namely The Circular Model of SoMe from Regina Luttrell. This study used a descriptive qualitative method and this study contained 3 key informats and 5 informants in this study. The results showed that at the share stage, the instagram social media chosen by KOPHI community was appropriate. In the optimize stage, the use of instagram @, kophi is quite optimal but KOPHI does not have a spacific strategy in developing its instagram account. At the manage stage, to carry out media monitoring KOPHI community uses Insight Instagram Analytics. At the engage stage, it is known that KOPHI Instagram followers do not always actively follow KOPHI Instagram developments and rarely respond to KOPHI Instagram posts. KOPHI community continues to optimize the use of the Instagram feature to support publication on their Instagram accounts.
\end{abstract} Keywords: Koalisi Pemuda Hijau Indonesia (KOPHI), Instagram, The Circular Model of SoMe

\begin{abstract}
ABSTRAK
Koalisi Pemuda Hijau Indonesia (KOPHI) komunitas yang bergerak dibidang lingkungan ini, kerap kali membahas mengenai isu dan fenomena yang terjadi saat itu. Dalam melakukan kegiatannya tim Divisi Media dan Komunikasi (MedKom) KOPHI memanfaatkan media sosial instagram sebagai media publikasi kegiatan, studi deskriptif: pada akun Instagram @_kophi. Akan tetapi, rendahnya engagement instagram menjadi hambatan dalam meraih feedback dari followernya. Tujuan penelitian ini adalah untuk mengetahui bagaimana pemanfaatan media sosial instagram@_kophi melalui beberapa tahap share, manage, optimize, dan manage. Penelitian ini menggunakan teori utama media sosial yaitu The Circular Model of SoMe dari Regina Luttrell. Penelitian ini menggunakan metode deskriptif kualitatif serta penelitian ini terdapat 3 key informan dan 5 informan dalam penelitian ini. Hasil penelitian menunjukan pada tahap share, media sosial instagram yang dipilih komunitas KOPHI ini sudah tepat. Pada tahap optimize, pemanfaatan instagram @_kophi cukup optimal namun KOPHI tidak memiliki strategi khusus dalam mengembangkan akun instagramnya. Pada tahap manage, untuk melakukan media monitoring komunitas KOPHI menggunakan analitik insight instagram. Pada tahap engage, diketahui follower instagram KOPHI tidak selalu aktif mengikuti perkembangan instagram
\end{abstract}


KOPHI dan jarang memberikan respon pada postingan instagram KOPHI. Komunitas KOPHI terus mengoptimalkan penggunaan fitur instagram untuk mendukung publikasi di akun instagramnya.

Kata Kunci: Koalisi Pemuda Hijau Indonesia (KOPHI), Instagram, The Circular Model of SoMe.

\section{PENDAHULUAN}

Internet di Indonesia telah menjadi sumber utama dalam memberikan kemudahan masyarakat untuk mencari informasi. Internet sebagai media komunikasi memberikan kemudahan bagi penggunanya mengakses informasi. Media sosial dalam internet membuat komunikasi lebih mudah dan cepat. Kekuatan media sosial yaitu mempengaruhi publiknya, dengan menjadikan media sosial sebagai sarana berbagi dan bertukar informasi. Beberapa contoh media sosial diantaranya Facebook, Twitter, Youtube, dan Instagram. Setiap platform media sosial memiliki fungsi yang hampir sama namun memiliki keunggulannya masing-masing.

Hal yang dapat dilakukan dalam publikasi melalui media sosial yaitu dengan membangun konten yang menarik dan mendorong pengikutnya terhubung dengan informasi yang tersedia. Mengelola sebuah komunikasi lewat media sosial, pemanfaatan media sosial juga dilakukan oleh Koalisi Pemuda Hijau Indonesia (KOPHI) dalam mempublikasikan konten kegiatan di akun media sosial instagram @_kophi. Tujuannya agar publik dan pengikutnya mengetahui agenda kegiatan yang dimiliki komunitas KOPHI.

Agenda kegiatan yang dimiliki Koalisi Pemuda Hijau Indonesia (KOPHI) beragam. Mulai dari agenda internal yang disebut KOPHI santai, KOPHI berbagi, gathering calon anggota KOPHI, rapat internal, dan rapat kerja KOPHI Pusat. Koalisi Pemuda Hijau Indonesia (KOPHI) juga menjalin kolaborasi (kerja sama) dengan beberapa lembaga dan komunitas lainnya. Dengan mempublikaskan konten kegiatan di media sosial Instagram, masyarakat dapat menilai langsung kegiatan yang dimiliki komunitas penggerak peduli lingkungan ini.

Sebuah konten dikatakan hidup, jika konten tersebut memiliki aktivitas yang beragam. Ketika sebuah konten tidak adanya interaksi, maka ada sesuatu yang perlu di perhatikan terhadap konten tersebut. Media sosial memiliki dua faktor yang mempengaruhi tingkat engagement dalam konten yaitu jumlah followers dan jumlah interaksi. Interaksi mempengaruhi nilai engagement dalam konten di media sosial.

Setiap postingan instagram KOPHI @_kophi pasti menginginkan adanya respon dari followers di setiap postingan. Publik dapat memberikan respon atau tanggapan dari postingan yang disukainya dengan meninggalkan jejak dalam bentuk tanda suka (like), 
komentar (comment) atau bahkan memilih membagikan (share) postingan tersebut. Dengan adanya engagement rate instagram mempermudah Koalisi Pemuda Hijau Indonesia (KOPHI) mengukur nilai atau tingkat persentasi komunikasi interaksi pada konten yang dipublikasikan.

Regina Luttrell menciptakan sebuah model untuk melakukan perencanaan komunikasi di media sosial yaitu The Circular Model of Some (Model Sirkuler Media Sosial) dengan tujuan untuk memudahkan para praktisi media sosial melakukan komunikasi interaksi di media sosial (Regina Luttrell, 2019).

Terdapat empat aspek tahapan-tahapan dalam model ini, keempat aspek tahapan tersebut memiliki peran dalam bagiannya masing-masing. Berikut uraian Model Sirkuler Some (The Circular Model of SoMe) menurut Regina Luttrell dalam bukunya Social Media: How to Engage, Share, and Connect, antara lain:1) Share (berbagi), yaitu memahami bagaimana dan dimana follower berinteraksi; 2) Optimize (Optimisasi), yaitu mengoptimalkan setiap interaksi media sosial; 3) Manage (Mengelola), yaitu mengatur sistem manajemen media tersebut; 4) Engage (Melibatkan), yaitu membangun hubungan dengan melibatkan audience dan influencers menjadi bagian penting dalam mengelola media sosial (Regina Luttrell, 2016). Koalisi Pemuda Hijau Indonesia (KOPHI) memanfaatkan media sosial instagram sebagai media publikasi kegiatannya.

Pada tahap share: Memahami bagaimana dan dimana follower berinteraksi. Ini adalah kesempatan untuk menghubungkan, membangun kepercayaan, mengidentifikasi saluran yang memungkinkan interaksi yang tepat. Media sosial instagram KOPHI memiliki follower 2.896 followers dan memiliki jumlah 525 postingan pada Juli 2019. Pemanfaatan dilakukan untuk dapat menyebarkan informasi mengenai kegiatan KOPHI, di media sosial KOPHI dapat mengetahui konten apa yang paling banyak disukai oleh followernya dengan itu KOPHI akan serius mengembangkan konten yang paling banyak mendapat feedback bagus. Melalui instagram komunitas KOPHI dapat membagikan konten dengan menyampaikan pesan melalui gambar dan captions yang menarik minat followernya.

Pada tahap Optimize: Mengoptimalkan setiap interaksi adalah hal yang terpenting. Sebuah perencanaan komunikasi yang kuat, dioptimalkan dengan baik akan menghasilkan dampak maksimum pada pesan, brand, dan nilai. Tim divisi media dan komunikasi yang mengelola media sosial mengoptimalkan pemanfaatan instagram KOPHI untuk membagikan informasi-informasi yang berkaitan dengan lingkungan, visualisasi konten yang dibagikan berupa infografis, videografis, maupun gambar maupun video real 
mengenai isu atau peristiwa yang lagi viral atau banyak dibahas mengenai kondisi lingkungan saat ini, hal ini dapat menarik perhatian follower KOPHI. Tim divisi media dan komunikasi juga melakukan optimalisasi pada fitur-fitur di instagram yaitu hastag dan tag.

Pada tahap Manage: Dengan mengatur sistem manajemen media seperti dimana dapat terus mengikuti percakapan yang terjadi di real-time, menganggapi follower langsung, mengirim pesan pribadi, berbagi link, memantau percakapan dan mengukur keberhasilan atau kegagalan. Mantriks merupakan bagian integral dalam mengelola strategi sosial. Sebagai praktisi kita harus menggambarkan nilai upaya dan melaporkan kembali ke tingkat eksekutif. Tim divisi media dan komunikasi KOPHI dapat mengetahui hasil dari optimalisasi yang dilakukan dengan menggunakan fitur analitik instagram yaitu insight instagram, dengan fitur ini komunitas KOPHI mengetahui apakah optimalisasi tersebut berhasil dilihat dari meningkat jumlah engagement instagram@_kophi berupa jumlah follower, like, maupun viewers.

Pada tahap Engage: Mengelola strategi engagement merupakan hal yang sulit, tetapi ketika perusahaan menyadari manfaat dari keterlibatan otentik hubungan yang tepat depan dibangun. Keterlbatan komunitas KOPHI dengan follower masih rendah, hal ini karena KOPHI sendiri tidak memiliki influencer yang membuat KOPHI dikenal. Namun KOPHI punya cara sendiri untuk membangun hubungan antara KOPHI dan followernya dengan membuat event atau kegiatan yang berkaitan dan melibatkan masyarakat dan followernya, seringkali KOPHI mengadakan konten kegiatan dalam bentuk collaboration (kerjasama) dengan beberapa organisasi, lembaga maupun komunitas dengan latarbelakang sama.

Penulis sebelumnya melakukan observasi pada akun instagram KOPHI yang akan dijadikan penelitian. Pada saat melakukan observasi, peneliti menemukan hal yang menarik yaitu KOPHI sendiri merupakan komunitas berbasis peduli dan pelestari lingkungan yang mempunyai branding bagus karena komunitas KOPHI sudah memiliki sebanyak 39 kepengurusan KOPHI daerah tersebar diseluruh provinsi Indonesia. Tetapi KOPHI pusat ini yang memiliki akun instagram @_kophi memiliki jumlah engagement instagram rendah.

Penulis menggunakan website www.sociabuzz.com untuk mengetahui jumlah engagement instagram KOPHI, didapat engagement rate instagram KOPHI sebesar 1,59\% dengan persentase yang sama sebesar 46 pada engagement postingan dan like, namun tidak ada persentase engagement pada comment yang diterima. Setiap bulan followers KOPHI mengalami peningkatan namun masih tidak sebanding dengan feedback yang diterima akun instagram@_kophi. 


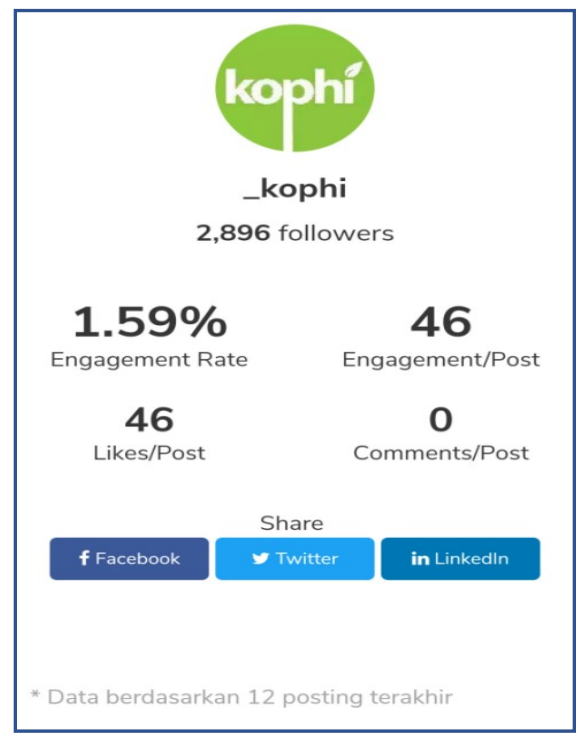

Gambar 1. Engagement Instagram @_kophi pada Juli 2019

(Sumber: https://socialbuzz.com)

Didapat persentase engagementinstagram @_kophi mendapat nilai rendah, ini tidak sebanding dengan banyaknya jumlah follower dan pada topik permasalahan penelitian ini membuat penulis tertarik dengan menggunakan konsep dari Regina Luttrell, meliputi 4 tahapan yaitu share, optimize, manage dan engage. Penulis tertarik melakukan penelitian dengan mengkaji aktivitas penggunaan media sosial pada apa yang dipublikasikan di akun instagram@_kophi dengan tujuan untuk meningkatkan nilai engagement instagram KOPHI, yaitu dengan fokus penelitian adalah 'Bagaimana pemanfaatan media sosial instagram@_kophi yang dilakukan oleh Koalisi Pemuda Hijau Indonesia (KOPHI) sebagai media publikasi kegiatannya'. Hal tersebut membuat penulis tertarik untuk mengetahui pemanfaatan dan pengelolaan instagram KOPHI melalui konsep dari Regina Luttrel dalam bukunya Social Media: How to Engage, Share, and Connect, meliputi 4 tahapan yaitu share, optimize, manage, dan engage.

Penulis membandingkan penelitian ini dengan beberapa penelitian lainnya yang membahas mengenai pemanfaatan dan pengelolaan media sosial dengan menggunakan konsep pemanfaatan media sosial dan konsep penelitian yang menggunakan model sirkuler SoMe. Dengan tujuan yaitu untuk mengetahui bagaimana pemanfaatan media sosial dari objek yang berbeda dan konsep yang berbeda juga.

Penelitian lain yang sejenis adalah membahas mengenai manajemen aktivitas media sosial akun instagram@indonesiabaik.id. Metode penelitian ini adalah deskriptif kualitatif dengan landasan konsep yang digunakan ialah The Circular Model of SoMe. Hasil penelitian penggunaan instagram pada tim indonesiabaik.id dinilai tepat karena saat ini 
banyak pengguna instagram di Indonesia. 1) Pada tahap share, indonesiabaik.id memilih instagram dengan latar belakang yang berpacu kepada Intruksi Presiden No. 9 Tahun 2015, serta menentukan target sasaran usia 20-34 tahun diprediksi adanya fenomena bonus demografi dan membangun kepercayaan publik dengan mencantumkan sumber di postingan. 2) Pada tahap optimize, indonesiabaik.id melakukan pengecekan hastag dan mention secara manual, serta setiap postingan sudah dijadwalkan dirapat mingguan. 3) Pada tahap manage, indonesiabaik.id melakukan media monitoring dengan laporan perminggu juga menggunakan website analytic Squarelovin dalam melihat postingan yang paling banyak diminati publik, melakukan quick respon dengan cepat membalas komentar, dan menjalin interaksi sebagai upaya real-time interaction dengan melakukan kegiatan live insta-story pada fitur di instagram.

4) Pada tahap engage, @indonesiabaik.id belum memiliki brand influencer tetapi melakukan sosialisasi ke kampus-kampus dan ingin menarik beberapa komunitas seperti pelatihan yang bernama SohIBerkelas, indonesiabaik.id melakukan riset dan memilih digital native yaitu Instagram dan Facebook sebagai target audiens, tim indonesiabaik.id membuat quiz di Instagram dalam meraih audiensnya namun tidak berhasil (Hajati, Perbawasari, Hafiar, 2018). Beberapa perbandingan penelitian ini dengan penelitian penulis, adanya kesamaan dalam meneliti untuk mengetahui pengelolaan media sosial yang dipilih yaitu instagram dengan memfokuskan penelitian dengan menggunakan landasan konsep dari Regina Luttrel dalam bukunya Media social How to engage, share, and connect. Namun penelitian tersebut memiliki objek kajian penelitian yang berbeda, yaitu pada pemerintahan dengan mengkaji pengelolaan media sosial pada akun instagram @indonesiabaik.id yang dikelola oleh Kementerian Komunikasi dan Informatika Republik Indonesia, sedangkan objek penelitian penulis pada akun instagram @_kophi oleh komunitas Koalisi Pemuda Hijau Indonesia (KOPHI), adapun hal yang menjadi fokus penelitian penulis ialah rendahnya engagement instagram @_kophi.

Terdapat penelitian sejenis yang membahas mengenai manajemen media sosial Instagram@Humas_jabar. Metode penelitian ini adalah deskriptif kualitatif dengan landasan konsep adalah The Circular of SoMe. Hasil penelitian mengungkapkan bahwa Humas Jabar dalam mengetahui manajemen Instagram @Humas_jabar belum optimal. 1) Pada proses share, pemilihan instagram dengan latar belakang Humas Jabar untuk membuka komunikasi dua arah dengan masyarakat, implementasi Permenpan No. 83 tahun 2012 menyediakan saluran kritik dan saran bagi masyarakat. 2) Pada proses optimize, 
Humas Jabar melakukan pengecekan fitur hastag dan mention secara manual, serta menargetkan satu kali satu posting yang hanya mengacu pada kuantitas postingan yaitu minimal satu kali sehari. 3) Pada proses manage, Humas Jabar untuk melakukan media monitoring menggunakan website analitik adalah iconosquare.com, namun memiliki kendala pembiayaan perbulan yang cukup mahal, pilihan lain dalam melakukan media monitoring Humas dilakukan secara manual dengan mengecek notifikasi serta belum konsisten dalam merespon komentar hanya dilakukan sore hari dan pendekatan menggunakan bahasa sunda, serta melakukan interaksi real-time dengan followers dengan live instagram dan membalas pertanyaan yang masuk belum konsisten menggunakan interaksi real-time.

4) Pada tahap engage, Humas Jabar melakukan kerjasama dengan komunitas kelana dua roda, namun kerjasama hanya bersifat sementara, serta menentukan target audience ialah umur anak SMP sampai orang tua, dalam meraih audience Humas Jabar membuat kompetisi foto dan membuat quiz namun belum konsisten (Romadhoni, Hafiar, Komariah, 2017). Beberapa perbandingan penelitian ini dengan penelitian penulis, adanya kesamaan dalam meneliti untuk mengetahui perkembangan media sosial yang dipilih yaitu instagram dan memfokuskan penelitian dengan menggunakan landasan konsep dari Regina Luttrel dalam bukunya Media social How to engage, share, and connect. Namun penelitian tersebut memiliki objek kajian penelitian yang berbeda, yaitu pada pemerintahan dengan mengkaji pengelolaan media sosial pada akun instagram@Humas_jabar yang dikelola oleh Humas Pemerintahan provinsi Jawa Barat, sedangkan objek penelitian penulis pada akun instagram@_kophi oleh komunitas Koalisi Pemuda Hijau Indonesia (KOPHI), adapun hal yang menjadi fokus penelitian penulis ialah rendahnya engagementinstagram@_kophi.

Terdapat penelitian lain dengan tujuan mengetahui perencanaan komunikasi melalui Instagram oleh@holidayinnbandung. Metode penelitian ini adalah deskriptif kualitatif dengan landasan konsep adalah The Circular of SoMe. Hasil penelitian menunjukan perencanaan komunikasi melalui instagram @holidayinnbandung cukup optimal. 1) Pada proses share, pemilihan instagram di latar belakangi oleh keberhasilan penggunaan hastag oleh IHG Internasional serta menentukan target sasaran yaitu keluarga demografis menengah keatas usia 20-55 tahun di Jakarta dan Bandung. dan bagaimana cara Holiday Inn Bandung dalam membangun kepercayaan publik. 2) Untuk proses optimize, perencanaan diawali dari promo yang dibuat melalui optimalisasi konten dengan memerhatikan aspek foto dan caption. 3) Pada tahap manage, dilakukan media monitoring 
yang terdapat pada website-website analitik seperti pixlee dan insight instagram, serta proses merespon feedback dari calon pelanggan dari follower dilakukan secara manual. 4) Untuk proses engage, perencanaan dilakukan dengan menggunakan brand influencer dan membuat konten yang atraktif agar dapat menghibur dan berinteraksi dengan followers (Satyadewi, Hafiar, Nugraha, 2017).

Beberapa perbandingan penelitian ini dengan penelitian penulis, adanya kesamaan dalam meneliti untuk mengetahui peengelolaan media sosial yang dipilih yaitu instagram dan memfokuskan penelitian dengan menggunakan landasan konsep dari Regina Luttrel dalam bukunya Media social How to engage, share, and connect. Namun penelitian tersebut memiliki objek kajian penelitian yang berbeda, yaitu pada perusahaan dengan mengkaji perencanaan komunikasi pada akun instagram @holidayinnbandung yang dikelola oleh Public Relations Manager Hotel Holiday Inn Bandung, sedangkan objek penelitian penulis pada akun instagram @_kophi oleh komunitas Koalisi Pemuda Hijau Indonesia (KOPHI), adapun hal yang menjadi fokus penelitian penulis ialah rendahnya engagementinstagram@_kophi.

Penelitian lainnya yang masih membahas pemanfaatan media sosial untuk penyebaran Informasi Kegiatan Sekolah Menengah Kejuruan Pasundan Tangerang. Metode penelitian ini adalah deskriptif kualitatif dengan landasan konsep adalah media sosial. Hasil penelitian menunjukan bahwa 1) Perlu dibangun sebuah media sosial bagi SMK Pasundan sebagai media penyebaran informasi yang berkaitan dengan akademik, pengumumanpengumuman seperti lomba-lomba di internal sekolah atau antar sekolah dengan menampilkan informasi kegiatan sekolah, ekstrakulikuler sekolah ataupun kegiatan baik siswa maupun guru. 2) Dilakukan juga pelatihan pada guru dan siswa, namun adanya kendala pada koneksi internet yang tidak ada, dengan disediakan modem untuk solusi sementara. Tersedianya media sosial seperti Facebook belum dioptimalkan secara optimal bagi pengembangan SMK Pasundan Tangerang, karena belum adanya akses internet di lingkungan SMK Pasundan Tangerang, padahal kebutuhan akses internet menjadi kebutuhan utama ketika ingin memanfaatkan media sosial.

3) Untuk mengatasi kendala yang berkaitan dengan akses internet, pihak sekolah melakukan manajemen postingan yang dilakukan secara berkala dengan membuat daftar postingan yang ingin diupload (Widayanti, 2015). Beberapa perbandingan penelitian ini dengan penelitian penulis, adanya kesamaan dalam meneliti untuk mengetahui pemanfaatan media sosial dan memfokuskan penelitian dengan menggunakan landasan konsep adalah 
media sosial. Namun penelitian tersebut memiliki objek kajian penelitian yang berbeda, yaitu pada lembaga pendidikan dengan mengkaji pengelolaan media sosial pada akun Facebook SMK Pasundan Tangerang yang dikelola oleh SMK Pasundan, sedangkan objek penelitian penulis pada akun instagram @_kophi oleh komunitas Koalisi Pemuda Hijau Indonesia (KOPHI), adapun hal yang menjadi fokus penelitian penulis ialah rendahnya engagementinstagram@_kophi.

Penelitian lain yang menjadi perbandingan dengan penelitian penulis ialah penelitian pada objek yang sama dengan pembahasan yang mirip ialah perencanaan komukasi dengan membuat strategi komunikasi Koalisi Pemuda Hijau Indonesia (KOPHI) Kalimantan Timur dalam kegiatan Karang Mumus hari ini. Metode penelitian ini adalah deskriptif kualitatif dengan kerangka dasar teori komunikasi dengan model S-M-C-R. Hasil penelitian menunjukan terdapat perencanaan yaitu 1) Menentukan peranan komunikator, dengan memilih tokoh masyarakat yang dijunjung tinggi, disegani oleh masyarakat untuk dapat membangun komunikasi dan hubungan harmonis dengan masyarakat, karena itu KOPHI perlu merangkul tokoh masyarakat atau pejabat untuk mendukung aksi dan kampanye sosial. 2) Menentukan pesan, perencanaan pembuatan pesan dibuat KOPHI berdasarkan tema topik yang sedang terjadi menjadi isu lingkungan saat ini. KOPHI menjadi fasilitator dan rekanan dengan komunitas lain berusaha untuk melakukan aksi melalui sosialisasi dan edukasi yang dapat mempengaruhi masyarakat. Penyampaian pesan lain juga menggunakan media konvensional serta menggunakan media sosial untuk menyebarkan pesan lebih luas. Pesan disampaikan kepada masyarakat pinggiran sungai hingga remaja generasi muda.

3) Menentukan jenis komunikasi, komunikasi yang dilakukan cukup beragam namun karena yang menjadi sasaran kepada warga sekitar Sungai Karang Mumus, maka KOPHI Kaltim menggunakan komunikasi langsung tatap muka dan komunikasi melalui media cetak maupun elektronik. 4) Menentukan sasaran, tertuju kepada masyarakat sekitar Sungai Karang Mumus, untuk harapan besar KOPHI kaltim adalah adanya kesadaran dari masyarakat umum lainnya atau masyarakat luas yakni masyarakat Kota Samarinda. KOPHI Kaltim lebih mengkampanyekan atau mensosialisasikan tentang kebersihan lingkungan yang sasarannya siswa sekolah, karena dirasa anak-anak mudah menangkap dan mengerti pesan melalui kegiatan. 5) feedback yang diharapkan, yaitu tercapainya sasaran serta perubahan dari perilaku dan kepribadian masyarakat untuk menjaga kebersihan sungai (Dwistiawan, Hariyati, Wibowo, 2018). Beberapa perbandingan penelitian ini dengan 
Handini Prabawati, Wasono Adi

penelitian penulis, adanya kesamaan pada objek penelitian yaitu komunitas Koalisi Pemuda Hijau Indoensia (KOPHI) dan penyampaian pesan yang digunakan adalah media sosial. Namun penelitian ini memiliki pembahasan yang berbeda yaitu dengan fokus penelitian menggunakan konsep teori komunikasi dari model S-M-C-R. sedangkan fokus penelitian penulis ialah menggunakan model sirkuler SoMe (The Circular Model Of Some) dari teori media sosial.

Terdapat beberapa landasan konsep dalam penelian ini. Ada tiga kemampuan dari internet yang dinyatakan oleh Kadava yaitu mendapatkan informasi yang dibutuhkan, menyebarkan informasi dan menyampaikan informasi, melakukan koordinasi dalam suatu pembuatan keputusan. Teknologi internet dapat digunakan oleh para aktivis untuk menyebarkan konten-konten pribadi maupun konten kampanye massal untuk tujuan promosi, penyampaian pesan kepada khalayak luas (Mary Joyce, 2010).

\section{Media Sosial}

Heidi Cohen mengatakan definisi media sosial terus berubah atau berkembang seiring dengan perkembangan penggunaan media sosial itu sendiri. Hal ini didukung oleh fakta bahwa media sosial berkaitan dengan teknologi dan platfrom yang memungkinkan pembuatan konten pada web interaktif sehingga terjadinya kolaborasi dan pertukaran pesan secara bebas antara para pengguna (Alo Liliweri, 2015).

Konten tetap menjadi pilihan utama untuk melihat bagaimana kebudayaan tumbuh dan berkembang di media sosial. Kehadiran media sosial, secara khusus memberikan arah komunikasi yang lebih interaktif (Rulli Nasrullah, 2017). Format konten yang dipublikasikan di media sosial pun beragam, mulai dari gambar, teks, audio, hingga audiovisual (Rulli Nasrullah, 2016).

Instagram adalah salah satu konten social media yang berbentuk aplikasi yang memungkinkan seseorang untuk berbagi foto atau video dengan terlebih dahulu memberikan filter digital kemudian memberikan caption dan membagikannya (Bambang, 2012). Instagram sebagai salah satu media sosial yang banyak digunakan sebagai tempat menyebarkan dan mendapatkan informasi, berinteraksi dengan orang banyak, serta dapat mengenal lebih dekat dengan sesama pengguna instagram melalui foto-foto dan video yang diunggah.

Berkembangnya social media yang begitu pesat membuat hampir semua orang memanfaatkan situs-situs jejaring sosial. Social media saat ini sudah menjadi ruang publik. Inovasi-inovasi platform sosial media baru lainnya seperti media sosial satu ini yaitu 
Handini Prabawati, Wasono Adi

Pemanfaatan Media Sosial Instagram Koalisi

Pemuda Hijau Indonesia (KOPHI) Sebagai

Media Publikasi Kegiatan

instagram. Instagram telah digunakan banyak komunitas, lembaga, maupun pemerintahan memanfaatkan media sosial untuk media publikasi kegiatan mereka. Menggunakan media sosial sebagai sarana baru penunjang untuk melakukan publikasi mereka (Mufrida Sofiana, 2016).

\section{The Circular Model of Some (Model Sirkuler SoMe)}

Regian Luttrell menciptakan sebuah model untuk melakukan perencanaan komunikasi di media sosial yaitu The Circular Model of Some (Model Sirkuler SoMe) menurut Regina Luttrell dalam bukunya Social Media: How to Engage, Share, and Connect, dengan tujuan untuk memudahkan para praktisi media sosial melakukan komunikasi interaksi di media sosial (Regina Luttrell, 2019). Terdapat empat aspek tahapan-tahapan dalam model ini, keempat aspek tahapan tersebut memiliki peran dalam bagiannya masing-masing yang terdiri dari Share, Optimize, Manage, dan Engage.

Berbagai peluang melalui pemanfaatan media sosial instagram@_kophi, dievaluasi melalui model tahapan mengelola media sosial, diantara lain:

- Share (berbagi), yaitu menggunakan strategi dalam mengelola media sosial

- Optimize (Optimisasi), yaitu mengoptimalkan konten yang bagikan

- Manage (Mengelola), yaitu bagaimana mengelola konten di media sosial

- Engage (Melibatkan), yaitu menjaga hubungan dengan follower dan melibatkan influencer menjadi bagian penting dalam mengelola media sosial.

\section{METODE PENELITIAN}

Penelitian ini penulis menggunakan metode penelitian deskriptif kualitatif dan paradigma yang digunakan penulis adalah paradigma post-positive. Paradigma ini mengatakan bukan hanya terlibat, terasa, dan teraba saja tetapi mencoba memahami makna dibalik yang ada. Realitas sosial menurut paradigma ini adalah suatu gejala yang utuh terkait dengan konteks, bersifat kompleks, dinamis dan penuh makna. Oleh karena itu, untuk mengetahui keberadaanya tidak dalam bentuk ukuran akan tetapi dalam bentuk eksplorasi untuk dapat mendeskripsikannya secara utuh (Satori dan Komariah, 2010.

Peneliti menggunakan paradigma post-positive, dengan berusaha memahami tahapan pemanfaatan media sosial instagram Koalisi Pemuda Hijau Indonesia (KOPHI) sebagai media publikasi kegiatan, dalam penelitian ini penulis tidak hanya mengelola data yang didapat tetapi peneliti mencari tahu setiap hal dan kejadian yang menyangkut penelitian ini. 
Subjek penelitian ini memiliki sumber informasi dari key informan dengan kriteria yaitu mereka yang terlibat langsung, mengetahui lebih dan memiliki berbagai informasi dalam pengelolaan dan pemanfaatan media sosial instagram KOPHI. Pemilihan Informan dalam penelitian ini adalah mereka yang dapat memberikan informasi tambahan dan mengetahui permasalahan sesuai dengan topik penelitian.

Teknik pengumpulan data merupakan langkah yang paling strategis dalam sebuah penelitan, sebab tujuan utama dari penelitian adalah mendapatkan data peneliti tidak akan mendapatkan data yang memenuhi standar yang ditetapkan (Sugiyono, 2013).Teknik pengumpulan data penelitian ini adalah melakukan observasi, metode pengumpulan data yang dilakukan peneliti untuk mengamati atau mencatat suatu peristiwa dengan penyaksian langsungnya, dan peneliti dapat sebagai partisipan atau observer dalam menyaksikan atau mengamati suatu objek peristiwa yang sedang diteliti, pada akun instagram @_kophi untuk mengetahui rateengagement akun instagram KOPHI. Pada penelitian ini, penulis melakukan wawancara mendalam kepada 3 key informan dan 5 informan yang mempunyai peranan dibidang pengelolaan dan pemanfaatan media sosial instagram KOPHI.

Untuk mendukung penelitian ini, penulis melakukan penelahaan dokumentasi berupa data sekunder. Data sekunder dianggap sebagai data pendukung untuk menambahkan keterangan, sebagai pelengkap dan sebagai bahan pembanding dalam suatu penelitian (Ikbar, 2014). Diperoleh data sekunder dari penelitian ini dengan penelahaan dokumentasi (documentary historical) melalui pengkajian buku, jurnal, skripsi dan artikel internet pada website http://kophi.or.id dan sumber lain sesuai dengan kajian penelitian.

Teknik analisis data dalam penelitian ini adalah deskriptif. Menurut Kasiran yang dimaksud dengan deskriptif adalah analisis hasil penelitian yang menggunakan data berupa kata-kata tertulis atau kalimat dari subjek yang diamati (Kasiran, 2010). Dalam penelitian ini penulis melakukan analisis dengan tahapan mengenai pemanfaatan media sosial instagram KOPHI sebagai media publikasi kegiatan.

Analisis jawaban subjek dengan meneliti kebenaran data empiris atau data lain yang tersedia. Dalam hal ini jawaban subjek di cross-check kan dengan dokumen lain (Ruslan, 2017). Untuk menjaga validasi data dilakukan dengan menggunakan triangulasi sebagai pembanding terhadap data tersebut. Teknik trianggulasi adalah pemeriksaan keabsahan data yang memanfaatkan sesuatu yang lain. Pada penelitian ini penulis menggunakan trianggulasi sumber, karena penulis membandingkan dengan data hasil pengamatan (observasi) dan hasil wawancara antara key informan dan informan yang berbeda. 
HASIL DAN PEMBAHASAN

Media Publikasi Kegiatan

\section{Hasil Penelitian}

KOPHI memanfaatkan media sosial instagram untuk membagikan informasi mengenai KOPHI, salah satunya yang terasa dan terlihat feedbacknya yaitu publikasi konten melalui media sosial instagram, melalui instagram KOPHI dapat menyebarkan informasi secara luas yang diterima cepat oleh publik, juga membuat konten yang menarik melalui pemanfaatan fitur yang tersedia. Hal itu akan mempengaruhi publik untuk bergabung pada komunitas KOPHI dengan memposting dan menampilkan kegiatan-kegiatan KOPHI ataupun hal menarik lainnya.

Berdasarkan hasil wawancara dengan Wakil Divisi Media dan Komunikasi KOPHI, dalam upaya meningkatkan engagement instagram KOPHI. Koalisi Pemuda Hijau Indonesia (KOPHI) melakukan konten kerjasama (kolaborasi) dengan beberapa instansi, lembaga maupun komunitas dibidang penggerak pelestarian lingkungan dan bidang lainnya.

Adapun pernyataan dari follower KOPHI, mengenai alasan mereka mengikuti media sosial instagram KOPHI adalah konten-konten yang dibagikan itu menarik dan bersifat informatif. Menurut follower KOPHI ini mengatakan bahwa konten yang dibagikan dapat menambah pengetahuan dan merubah gaya hidup follower KOPHI. Berikut beberapa kegiatan dan publikasi di akun instagram KOPHI.

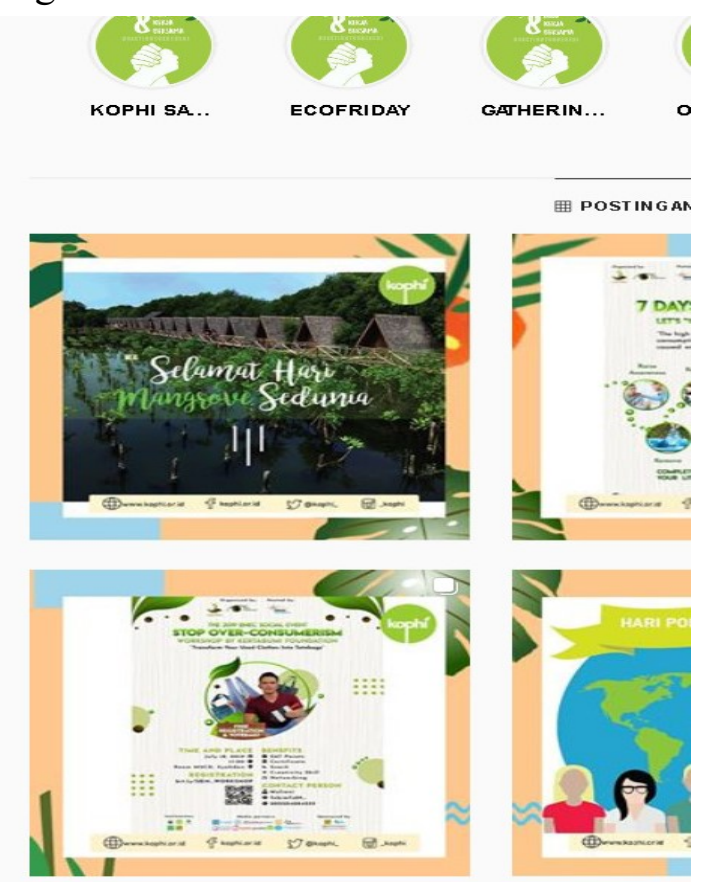

Gambar 2. Publikasi di akun Instagram KOPHI

(Sumber: https://instagram.com/ kophi) 
Gambar 3. Kegiatan KOPHI 2019

(Sumber: https://instagram.com/ kophi)

\section{Pembahasan}

Tujuan penelitian ini yaitu mengetahui pemanfaatan media sosial Instagram @_kophi dengan model sirkuler SoMe dari Regina Luttrell melalui tahapan (share), (optimize), (manage) dan (engage).

\section{Tabel}

Gambar 4. Tahapan pengelolaan media sosial

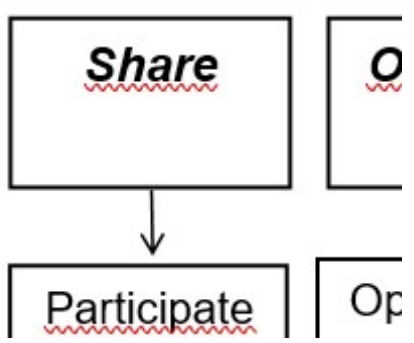

Sumber: Handini Prabawati

\section{Tahap Share}

Media sosial instagram yang dipilih komunitas KOPHI ini sudah tepat. Karena target sasaran KOPHI adalah anak-anak muda. Di instagram banyak penggunanya anak muda. Adapun alasan follower mengikuti media sosial instagram KOPHI ialah kontenkonten yang dibagikan itu menarik dan bersifat informatif tapi postingan terlihat monoton. KOPHI pernah menggunakan fitur promote instagram untuk membantu publikasi. Upaya yang dilakukan KOPHI dalam membangun kepercayaan khalayaknya, dengan menyajikan data-data mengenai permasalahan lingkungan. 


\section{Tahap optimize}

Media Publikasi Kegiatan

Komunitas KOPHI dalam mengoptimalkan konten yang akan dipublikasikan, memiliki kalender agenda schedule dalam memposting di akun instagramnya. Namun dalam mengoptimalkan kontennya, komunitas KOPHI ini tidak memiliki strategi khusus untuk mengembangkan akun instagramnya. Konten kegiatan yang menarik bagi follower KOPHI ialah eco-friday, konten yang dibagikan di instastory instagram KOPHI. Konten yang menarik bagi follower KOPHI salah satunya saat event peringatan hari besar yaitu Hari Sumpah Pemuda, komunitas KOPHI juga melibatkan follower untuk gabung dalam program bersih-bersih pulau. Menurut follower KOPHI, konten yang menarik bagi follower KOPHI adalah konten yang bersifat dan kearah millienial agar dapat sesuai dengan target khalayak KOPHI ialah anak-anak muda yang tertarik pada lingkungan.

\section{Tahap manage}

Untuk melakukan media monitoring komunitas KOPHI menggunakan analitik media sosial instagram seperti insight instagram. Upaya meningkatkan engagement instagram KOPHI. Koalisi Pemuda Hijau Indonesia (KOPHI) mengadakan konten kerjasama (media partner) saat event hari besar nasional. Follower KOPHI mengatakan publikasi yang dibagikan di akun instagram KOPHI masih dinilai kurang informatif dan terlihat monoton posting mengenai hari-hari besar nasional tentang lingkungan. Konten yang dibagikan itu cukup menarik karena konten yang disajikan berupa infografis.

\section{Tahap engage}

Follower KOPHI pun tidak terlalu aktif untuk memberikan respon pada postingan di instagram@_kophi. Ini yang membuat jumlah engagement instagram KOPHI rendah, hal tersebut tidak sebanding dengan jumlah follower instagram yang mencapai dua ribu followers. Komunitas KOPHI tidak memiliki brand influencer untuk mempengaruhi khalayaknya pada postingan yang dibagikan. Tetapi untuk mendukung publikasi di akun instagram@_kophi, komunitas KOPHI memanfaatkan beberapa fitur-fitur instagram. Namun komunitas KOPHI ini masih belum optimal dalam menggunakan dan memanfaatkan fitur-fitur instagram. Dari feedback yang diterima sering kali KOPHI kurang cepat dalam menangapi pada feedback yang masuk. Butuh waktu paling lambat 1-2 hari terbalas, hal ini karena beberapa admin instagram KOPHI memiliki latarbelakang aktivitas yang berbeda. 
PENUTUP

Kesimpulan

Konsep yang digunakan dalam penelitian ini adalah menggunakan landasan konsep teori media sosial dengan Model Sirkuler Some (The Circular Model of SoMe) dari Regina Luttrell, yang menjelaskan tahapan pengelolaan media sosial apakah berhasil atau tidak. Berikut tahapan mengelola media sosial penelitian ini, diantara lain:

Hasil penelitian melalui tahap Share (berbagi), yaitu pemilihan media sosial instagram sebagai media publikasi menjadi pilihan tepat karena sesuai dengan target sasaran KOPHI ialah anak muda yang punya ketertarikan pada isu lingkungan. Tahap Optimize (Optimisasi), yaitu dalam mengoptimalkan konten yang akan dipublikasikan komunitas KOPHI memiliki kalender agenda schedule dalam memposting di akun instagramnya. Namun dalam pengelolaanya Koalisi Pemuda Hijau Indonesia (KOPHI) tidak punya strategi khusus untuk mengembangkan media sosial instagramnya. Pada tahap Manage (Mengelola), komunitas KOPHI kurang konsisten dalam memposting, hal ini yang membuat rendahnya engagement instagram KOPHI. Upaya meningkatkan engagement instagram KOPHI, Koalisi Pemuda Hijau Indonesia (KOPHI) mengadakan konten kerjasama (media partner) saat event hari besar nasional pada event tersebut KOPHI dapat meningkatkan branding mereka sebagai komunitas penggerak lingkungan.

Sedangkan pada tahap Engage (Melibatkan), yaitu diketahui follower instagram KOPHI tidak selalu aktif mengikuti perkembangan postingan instagram KOPHI dan jarang memberikan respon pada konten yang diupload di akun instagramnya. Hal Ini yang membuat jumlah engagement instagram KOPHI rendah, ini tidak sesuai dengan jumlah follower instagram yang mencapai dua ribu followers. Komunitas KOPHI tidak memiliki brand influencer untuk mempengaruhi khalayaknya pada postingan yang dibagikan. Tetapi untuk mendukung publikasi di akun instagram @_kophi, tim Divisi Media dan Komunikasi (MedKom) KOPHI memanfaatkan beberapa fitur-fitur instagram.

\section{DAFTAR PUSTAKA}

Bambang. (2012). Instagram Handbook. Jakarta: Media Kita.

Dwistiawan, E., Hariyati., Wibowo, S. E., (2018). "Strategi Komunikasi Koalisi Pemuda Hijau Indonesia (KOPHI) Kalimantan Timur dalam Kegiatan Karang Mumus hari ini." e-Jurnal Ilmu Komunikasi. Vol. 6 No. 3.

Falls, Jason. 2012. Defining Engagement. Diakses dari http://socialmediaexplorer.com/content-sections/news-and-noise/defining-engagement/ \begin{tabular}{ll}
\hline Hajati, R. P., Perbawasari, S., \& Hafiar, H. (2018). "Manajemen Aktivitas Media Sosial & Akun \\
Instagram @INDONESIABAIK.ID”. Journal of Communication. & Vol. 3 No. 2.
\end{tabular}

Joyce, Mary (ed). (2010). Digital Activism Decoded: The New Mechanics of Change. NewYork: IDEVATE Press. 
Kasiran. (2010). Metodelogi Penelitian Kuantitatif dan Kualitatif. Malang: UIN Press

Liliweri, Alo. (2015). Komunikasi Antar-Personal. Jakarta: Kencana Prenada media Group.

Luttrell, Regina . (2019). Social Media: How To Engage, Share, and Connect, Lanham: Rwman \& Littlefield, Third Edition.

Luttrell, Regina. (2016). Social Media: How To Engage, Share, and Connect, $\quad$ Rwman \& Littlefield, Second Edition.

Mayasari, S., \& Indraswari, C. (2018). "Efektivitas media sosial instagram dalam media publikasi HUT Museum Nasional Indonesia (MNI) kepada Masyarakat”. Jurnal Komunikasi. Vol. 9 No. 2.

Memahami istilah engagement di media sosial. 2015. Diakses dari $\quad$ http://yellowcabin.com Profil KOPHI. 2018. Diakses dari http://www.kophi.or.id/profil-kophi/

Nasrullah, Rulli. (2016). Teori dan Riset: Media Siber (CyberMedia). Jakarta: Kencana Prenadamedia Group.

Nasrullah, Rulli . (2017). Media Sosial: Perspektif Komunikasi, Budaya, dan Sosioteknologi, Bandung: Simbiosa Rekatama Media.

Romadhoni, A., Hafiar, H., \& Komariah, K. (2017). “Pengelolaan Instagram @Humas_jabar oleh Bagian Humas Pemerintah Provinsi Jawa Barat”. Jurnal Ilmu Komunikasi. Vol. 8 No. 2.

Ruslan, Rosady. (2017). Metode Penelitian: Public Relations dan Komunikasi. $\quad$ Cetakan ke-7. Jakarta: Rajawali Pers.

Satyadewi, A. J., Hafiar, H \& Nugraha, A. R. (2017). "Pemilihan AkunMediaSosial Instagram oleh Holiday Inn Bandung”. Jurnal the Messenger. Vol. 9 No. 2.

Sofiana, Mufrida. (2016). Skripsi: Instagram Sebagai Media Publikasi Humas Pemerintahan Kota Surabaya.

Sugiyono. (2013). Metode Penelitian Kuantitatif, Kualitatif, dan Kombinasi Mixed Methods). Bandung: Alfabeta.

Ikbar, Yanuar. (2014). Metode Penelitian Sosial Kualitatif. Bandung: PT. Refika Aditama. 